\title{
Cost-effectiveness of telbivudine versus lamivudine for chronic hepatitis B
}

\begin{abstract}
Background and aim: Chronic hepatitis B is a highly prevalent disease worldwide, leading to serious consequences if not properly treated. Six treatment options for chronic hepatitis B are currently provided by the Brazilian public health system. Telbivudine is a nucleoside analogue that is neither included in the Brazilian clinical protocol nor in the therapeutic guidelines for chronic hepatitis B. Objective: The aim of this study was to evaluate the cost-effectiveness of telbivudine for the viewpoint of the Brazilian public system, comparing it to lamivudine. Methods: A Markov model was used to project lifetime complications and costs of treatment with lamivudine or telbivudine for chronic hepatitis B in both HBeAg-positive and HBeAg-negative patients. To evaluate disease progression, probabilities and utilities of virologic response, virologic resistance, compensated cirrhosis, decompensated cirrhosis, hepatocellular carcinoma, treatment, interruption of treatment, death and seroconversion were collected in systematic reviews. Costs were collected in DATASUS, ABC da Saúde and scientific literature. Results: Higher rate of virologic response and seroconversion was obtained with telbivudine, and also higher values of quality adjusted life years. However lamivudine is associated with lower costs and also lower cost-effectiveness values. The incremental cost-effectiveness ratios for telbivudine, when compared with lamivudine, were US\$30,575 and US\$ 40,457, respectively for HBeAg-positive and HBeAg-negative patients. Conclusions: In chronic hepatitis B lamivudine is a more cost-effective or even cost-saving strategy when compared with telbivudine.
\end{abstract}

Keywords: lamivudine; cost-effectiveness evaluation; hepatitis B, chronic.

[Braz J Infect Dis 2011;15(3):225-230]@Elsevier Editora Ltda.

\section{INTRODUCTION}

Currently, more than two billion people have been infected by hepatitis B virus (HBV), and about 350 million remain chronically infected, and more than 500,000 people die annually due to diseases related to HBV infection. ${ }^{1}$ It is estimated that chronic hepatitis $\mathrm{B}(\mathrm{CHB})$ is among the ten leading causes of death worldwide. ${ }^{2}$ Individuals with $\mathrm{CHB}$ have also increased risk of developing liver cirrhosis and hepatocellular carcinoma, leading one million individuals annually to death. ${ }^{1,3,4}$

Treatments of $\mathrm{CHB}$ aim to prevent or to reduce the development of liver cirrhosis and hepatocellular carcinoma. They also aim viral suppression, normalization of alanine aminotransferase (ALT) levels, decrease liver damage and seroconversion. In Brazil, there are currently six approved drugs for use in CHB: lamivudine, interferon alpha (pegylated and conventional), entecavir, adefovir dipivoxil and tenofovir disoproxil fumarate..$^{5-7}$ Telbivudine is a drug used worldwide but not included in Brazilian therapeutic guidelines for $\mathrm{CHB}{ }^{8}$

Lamivudine was the first nucleoside analogue approved for the treatment of $\mathrm{CHB}$, showing to be beneficial by reducing HBV DNA levels, normalizing ALT and improving histological liver in short-term treatments. ${ }^{910}$ Lamivudine has potent action against reverse transcriptase. It inhibits the synthesis of HBV DNA from pre-genomic RNA, blocking the synthesis of new viral particles. ${ }^{2,11}$

Telbivudine is a nucleoside analogue with potent activity, selective and specific for hepa DNA virus and blocking viral replication. The commonly used dose is $600 \mathrm{mg} /$ day. ${ }^{9}{ }^{912}$ In the GLOBE study, the efficacy of telbivudine and lamivudine in $\mathrm{HBeAg}$-positive and HBeAg-negative patients with $\mathrm{CHB}$ was compared. Telbivudine leads to a rapid inhibition of $\mathrm{HBV}$ replication and was more effective when compared to lamivudine. ${ }^{12,13}$
Authors

Astrid Wiens ${ }^{1}$

Rafael Venson ${ }^{2}$

Cassyano Januário

Correr $^{3}$

Roberto Pontarolo

${ }^{1} \mathrm{MSc}$ in Pharmaceutical Sciences; PhD student in Pharmaceutical Sciences, Universidade Federal do Paraná (UFPR), Brazil ${ }^{2}$ Pharmacist; MSc student in Pharmaceutical Sciences; UFPR, Brazil

${ }^{3} \mathrm{MSc}$ in Pharmaceutical Sciences; PhD. in Internal Medicine and Health Sciences, UFPR; Professor at UFPR, Brazil

${ }^{4} \mathrm{MSc}, \mathrm{PhD}$ in Biochemistry; Professor at UFPR, Brazil

Submitted on: 11/22/2010 Approved on: 12/15/2010

Correspondence to:

Roberto Pontarolo Universidade Federal do Paraná - Departamento de Farmácia

Avenida Prefeito Lothário Meissner, 632 - Jardim Botânico

Curitiba - PR - Brazil 80210-170 pontarolo@ufpr.br

We declare no conflict of interest. 
The worldwide increasing technology incorporation, with introduction of new equipments, health products and medicines, which in the vast majority have high costs, implies to investigate whether the improvement in results is significant on the aggregate costs. In particular it is essential that the public manager have data for decisions of new technologies to the population.

The introduction of economic evaluation methods and the increase in pharmaceutical costs began to contribute to the claim for cost-effectiveness evaluations before use new technologies. ${ }^{14}$ Economic evaluation studies also show costs among the various treatment options available, contributing to harmonization of the growing health demands.

The aim of this study was to conduct a cost-effectiveness analysis comparing treatments with lamivudine and telbivudine for $\mathrm{CHB}$, thus providing information to the Brazilian public health system in the incorporation of telbivudine therapy.

\section{MATERIAL AND METHODS}

A systematic review was conducted by two independent reviewers, to compare efficacy of telbivudine and lamivudine. The electronic searches were conducted in the following databases: MEDLINE, Cochrane Library, SciELO, LILACS and International Pharmaceutical Abstracts. Only studies published in English, Portuguese, German or Spanish were included. The following words were used in the searches: chronic hepatitis $\mathrm{B}$, telbivudine, lamivudine and efficacy. Search filters were used to identify RCT. Only studies that directly compared the two drugs were included.

The studies were identified and selected and data were extracted using pre-prepared tables. In case of discrepancies in any previous steps, discordant results were resolved by consensus. Studies that compared treatments of telbivudine with lamivudine during 24 weeks were included. Doses of $600 \mathrm{mg} /$ day of telbivudine or $100 \mathrm{mg} /$ day of lamivudine were eligible for inclusion. Data about efficacy and safety were extracted from included studies.

For the costs of treatments, direct costs were calculated, including drugs, laboratory tests and medical consultations. Drug costs were calculated using " $A B C$ da Saúde" tables, used in Brazil as a reference, considering that the price of telbivudine is not available in public health systems, for not having been approved for use in CHB. Other costs, such as exams and medical consultations, were calculated from the DATASUS price tables of the public health system.

A Markov model was elaborated in the timeframe of ten years, allowing evaluating the possible phases of $\mathrm{CHB}$ and relevant over time, with each cycle of the model corresponding to six months. This model is useful in decision making, considering the continuing risk over time. Moreover, the duration of events that can occur more than once during the simulation, is of paramount importance in this model. To construct the model software was used TreeAge ${ }^{\circledR}$ Pro 2009.
In the model, scenarios were created assuming health conditions and situations arising from the use of medicines and clinical pathology. The event sequences used were taken from studies found in systematic review and adapted with support of hepatologists. We adopted the scenario considering that the sequence of events that may occur are the same for both interventions, which varied the probabilities, costs and effectiveness of treatments. It was assumed that the age of patients that began treatment was 40 years.

It was assumed that all patients entering treatment are diagnosed with $\mathrm{CHB}$. The model compares two treatment options with telbivudine or lamivudine. Due to the different outcomes to treatment in $\mathrm{HBeAg}$ positive and negative patients, we performed a Markov model for the HBeAg-positive and another for $\mathrm{HBeAg-negative} \mathrm{patients.}$

We did not evaluate change of therapy.

As the outcome measure, treatment effectiveness was determined by the quality-adjusted life years (QALY). This measure takes into account both the quantity and quality of life resulting from treatment. Quality of life is estimated by using instruments to assess the perception of a given health condition in a value between two extreme points: 0 (death) and 1 (perfect health). This value, known as utility, is multiplied by time in which the individual spends in each state of health. For each Markov state of the literature, information regarding the utility of patients in the state was searched.

After defining the health states, the costs for each health state were also searched in the literature. These were added to the Markov model and added to the costs of treatment (with lamivudine or telbivudine).

Sensitivity analysis was performed to determine the robustness of the model by varying the value of some key variables used..$^{15}$ So it may lead to a decrease in the level of uncertainty in estimates of costs and their relationship with the effect of the intervention. A one way analysis of costs and effectiveness (measured by utility of virologic response and seroconversion) was performed for both treatment groups, varying them by $20 \%$. The discount rate was $5 \%$ for costs and effectiveness (utility of virologic response and seroconversion).

\section{RESULTS}

Nine citations in electronic databases were founded, of which four were excluded on the basis of title or abstract. The remaining five citations were evaluated by two independent reviewers. Among these, three studies were excluded after examination of the full text (different times of treatment or comparison to other drugs). The remaining two articles were included in our economic evaluation.

The estimated costs of each treatment are described in Table 1, and are calculated for the period of six months, which is a Markov cycle. The costs found for each health state were fixed to the current value (2010) and calculated for each cycle (Table 2). 
Table 1. Costs of procedure/drugs per unity and per cycle

\begin{tabular}{lccc}
\hline Procedure / Drug & Periodicity & Cost (US\$) & Cost per cycle (US\$) \\
\hline Lamivudine $150 \mathrm{mg}$ & Daily & 4.72 & $861.35^{*}$ \\
\hline Telbivudine 600 mg & Daily & 17.49 & $3,191.27^{*}$ \\
\hline Hemogram with platelet count & Every 3 months & 2.48 & $4.95^{* *}$ \\
\hline ALT/AST & Every month & 1.21 & $7.27^{* *}$ \\
\hline TSH & Every 3 months & 7.96 & $15.91^{* *}$ \\
\hline Fasting glucose & Every 3 months & 1.12 & $2.23^{* * *}$ \\
\hline Medical visit & Every 6 months & 6.03 & $6.03^{* *}$
\end{tabular}

ALT, alanine aminotransferase; AST, aspartate aminotransferase; TSH, thyroid-stimulating hormone.

* according $\mathrm{ABC}$ tables

$* *$ according DATASUS tables

Table 2. Costs of each health state, annual and per cycle fixed to current values ${ }^{16}$

\begin{tabular}{lccccc}
\hline Procedure & Clinical follow-up & $\begin{array}{c}\text { Compensated } \\
\text { cirrhosis }\end{array}$ & $\begin{array}{c}\text { Decompensated } \\
\text { cirrhosis }\end{array}$ & $\begin{array}{c}\text { Hepatocarcinom } \\
\text { Hepatic } \\
\text { transplant }\end{array}$ \\
\hline Annual cost (US\$) & 770.25 & 976.20 & $17,293.35$ & $3,741.70$ & $68,609.73$ \\
\hline Per cycle cost (US\$) & 385.12 & 488.10 & $8,646.68$ & $1,870.85$ & $34,304.86$ \\
\hline
\end{tabular}

We created the following health states in Markov model for $\mathrm{HBeAg}$-positive patients: virologic response, virologic resistance, compensated cirrhosis, decompensated cirrhosis, hepatocellular carcinoma, CHB-treatment, interruption of treatment, death and seroconversion. For
HBeAg-negativepatientsthestate seroconversion was withdrawn.

It was considered that all patients started treatment in the state CHB-treatment. In the next cycle, patients switched to other states according to the probabilities found in the literature review, described in Table 3.

Table 3. Probability of reaching each state of $\mathrm{CHB}$

\begin{tabular}{|c|c|c|c|c|}
\hline Initial state & State reached & Range lamivudine & Range telbivudine & Reference \\
\hline \multirow{6}{*}{ CHB } & Virologic resistance & 0.1188 & 0.0562 & 12,17 \\
\hline & Virologic response & 0.4637 & 0.5186 & 12,17 \\
\hline & $\mathrm{CC}$ & \multicolumn{2}{|c|}{0.0999} & 18 \\
\hline & $\mathrm{HC}$ & \multicolumn{2}{|c|}{0.0131} & 18,19 \\
\hline & Death & \multicolumn{2}{|c|}{0.0014} & 1 \\
\hline & Soroconversion* & 0.2063 & 0.2314 & 12,17 \\
\hline \multirow{2}{*}{$\begin{array}{l}\text { Virologic } \\
\text { resistance }\end{array}$} & Death & \multicolumn{2}{|c|}{0.029} & 18 \\
\hline & $\mathrm{HC}$ & \multicolumn{2}{|c|}{0.4782} & 19 \\
\hline \multirow{2}{*}{ Soroconversion } & $\mathrm{CC}$ & \multicolumn{2}{|c|}{0.0391} & 18 \\
\hline & $\mathrm{HC}$ & \multicolumn{2}{|c|}{0.0131} & 19 \\
\hline \multirow{3}{*}{$\mathrm{CC}$} & DC & \multicolumn{2}{|c|}{0.05} & 20 \\
\hline & Death & \multicolumn{2}{|c|}{0.029} & 18 \\
\hline & $\mathrm{HC}$ & \multicolumn{2}{|c|}{0.071} & 20 \\
\hline \multirow{2}{*}{$\mathrm{HC}$} & Transplant & \multicolumn{2}{|c|}{0.0008} & 20 \\
\hline & Death & \multicolumn{2}{|c|}{0.372} & 20 \\
\hline \multirow{3}{*}{ DC } & $\mathrm{HC}$ & \multicolumn{2}{|c|}{0.025} & 20 \\
\hline & Transplant & \multicolumn{2}{|c|}{0.014} & 20 \\
\hline & Death & \multicolumn{2}{|c|}{0.39} & 20 \\
\hline Transplant & Death & \multicolumn{2}{|c|}{0.15} & 20 \\
\hline
\end{tabular}

CC, compensated cirrhosis. CHB, chronic hepatitis B; DC, decompensated cirrhosis; HC, hepatocarcinom.

* only for HBeAg positive patients. 
The utility of patients in each of the health states found in the literature is described in Table 4.

Markov models for cost-effectiveness analysis of $\mathrm{HBeAg}$-positive and $\mathrm{HBeAg}$-negative patients are represented in Figures 1 and 2, respectively.
The effect, cost, cost-effectiveness and incremental costeffectiveness ratios (ICER) are described in Tables 5 and 6, respectively for HBeAg-positive and HBeAg-negative patients.

In sensitivity analysis (Table 7), the cost-effectiveness of lamivudine was superior to telbivudine in all analysis, emphasizing the results robustness.

Table 4. Utility of each disease state

\begin{tabular}{lcc}
\hline Health state & Utility & Reference \\
\hline Transplant & 0.5 & 20 \\
\hline Virologic resistance & 0.655 & Experts opinion \\
\hline Virologic response $\left(H B V\right.$ DNA $\left.<\log _{10}\right)$ & 0.755 & 21 \\
\hline Decompensated cirrhosis & 0.35 & 22 \\
\hline Treatment & 0.755 & 21 \\
\hline Treatment interruption & 0.8 & 21 \\
\hline Seroconversion & 0.755 & 22 \\
\hline Hepatocarcinom & 0.37 & 22 \\
\hline Compensated cirrhosis & 0.7 & 22 \\
\hline
\end{tabular}

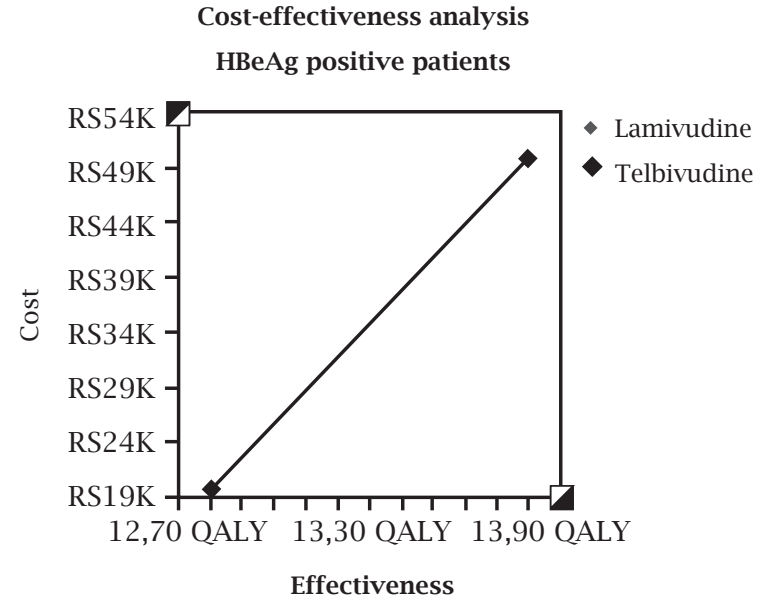

Figure 1: Cost-effectiveness analysis in HBeAg positive patients.

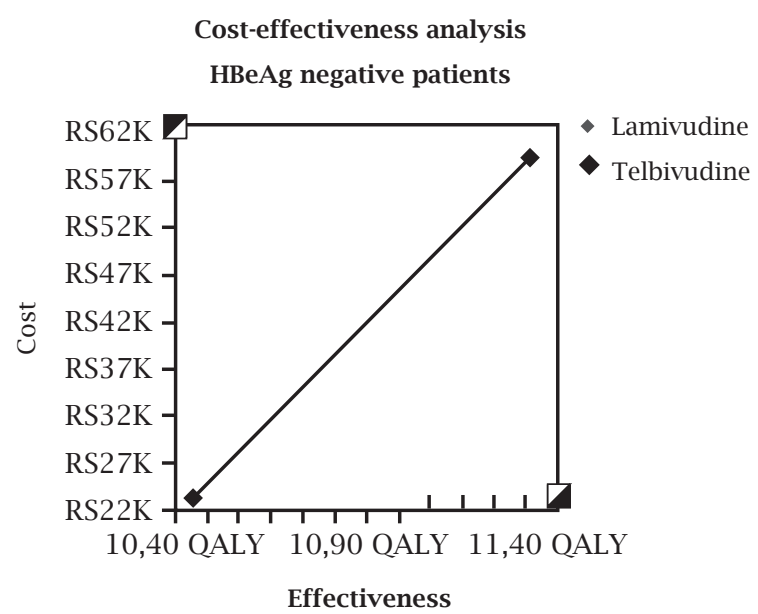

Figure 2: Cost-effectiveness analysis in HBeAg negative patients.

Table 5. Cost, effectiveness, cost-effectiveness and ICER of lamivudine and telbivudine for HBeAg positive patients

\begin{tabular}{lcccccc}
\hline & $\begin{array}{c}\text { Cost } \\
\text { (US\$) }\end{array}$ & $\begin{array}{c}\text { Incremental } \\
\text { cost (US\$) }\end{array}$ & $\begin{array}{c}\text { Effect } \\
\text { (QALY) }\end{array}$ & $\begin{array}{c}\text { Incremental } \\
\text { effect }\end{array}$ & C/E & $\begin{array}{c}\text { Incremental (US\$) } \\
\text { C/E (ICER) }\end{array}$ \\
\hline Lamivudine & 19,065 & & 12.79 & & 1,491 & 30,575 \\
\hline Telbivudine & 50,284 & 31,220 & 13.81 & 1.02 & 3,641 & \\
\hline
\end{tabular}

QALY, quality-adjusted life year; ICER, incremental cost-effectiveness ratio. 
Table 6. Cost, effectiveness, cost-effectiveness and ICER of lamivudine and telbivudine for HBeAg negative patients

\begin{tabular}{lcccccc}
\hline & $\begin{array}{c}\text { Cost } \\
\text { (US\$) }\end{array}$ & $\begin{array}{c}\text { Incremental } \\
\text { cost (US\$) }\end{array}$ & $\begin{array}{c}\text { Effect } \\
\text { (QALY) }\end{array}$ & $\begin{array}{c}\text { Incremental } \\
\text { effect }\end{array}$ & C/E & $\begin{array}{c}\text { Incremental } \\
\text { C/E (ICER) (US\$) }\end{array}$ \\
\hline Lamivudine & 22,649 & & 10.44 & & 2,170 & \\
\hline Telbivudine & 58,619 & 35,970 & 11.33 & 0.89 & 5,175 & 40,457 \\
\hline
\end{tabular}

QALY, quality-adjusted life year; ICER, incremental cost-effectiveness ratio.

Table 7. One way sensitivity analysis for costs and effects

\begin{tabular}{lccc}
\hline Variable & Basal value & Range & Value \\
\hline Cost lamivudine (US\$) & 897 & $20 \%$ & 1,077 \\
& & $-20 \%$ & 718 \\
\hline Cost telbivudine (US\$) & 3,227 & $20 \%$ & 3,873 \\
& & $-20 \%$ & 2,582 \\
\hline Virologic response & 0.4637 & $20 \%$ & 0.5564 \\
Lamivudine & & $-20 \%$ & 0.3709 \\
\hline Virologic response & 0.0562 & $20 \%$ & 0.0674 \\
Telbivudine & & $-20 \%$ & 0.0449 \\
\hline Soroconversion & 0.2063 & $20 \%$ & 0.2475 \\
Lamivudine & & $-20 \%$ & 0.1650 \\
\hline Soroconversion & 0.2314 & $20 \%$ & 0.2777 \\
Telbivudine & & $-20 \%$ & 0.1851 \\
\hline
\end{tabular}

\section{DISCUSSION}

Lamivudine is used for the treatment of $\mathrm{CHB}$ for over 20 years, with demonstrated effectiveness and safety. ${ }^{9,10}$ However, many patients suffer some viral mutation and develop viral resistance to the drug. ${ }^{11}$ In recent years, new drugs were developed for the disease, providing other treatment options. The efficacy and safety of telbivudine for the treatment of CHB has been shown previously. ${ }^{12,13}$ However, when there are new drugs to treat a disease, it is of great importance to evaluate its cost-effectiveness, comparing it to existing treatments. Due to the widespread use of lamivudine for the treatment of $\mathrm{CHB}$, it was used as the standard to be compared to telbivudine to evaluate cost-effectiveness of this study.

When evaluating the effectiveness data of both therapies separately, within six months of treatment there are higher seroconversion rates and better virologic response of telbivudine, and also lower rate of virologic resistance. However, this is not enough for a decision, especially in a disease of high prevalence worldwide. In such cases, it is of paramount importance that health care managers and physicians have information about the cost-effectiveness of available treatments, for a better allocation of available resources.
In the current study, we obtained values of QALY 12.79 and 13.81 for lamivudine and telbivudine, respectively, after 10 years of treatment in $\mathrm{HBeAg}$-positive patients, and 10.44 and 11.33, respectively, for HBeAg-negative patients. These values lead us to indicates similar effectiveness of both treatments. However, when evaluating the cost-effectiveness ratios, we found that this ratio is much higher for telbivudine, reaching an ICER of over than $\$ 30,000$ in both, $\mathrm{HBeAg}$-positive and $\mathrm{HBeAg}$-negative patients. In such cases, health system and physicians have to assess the benefits of each therapy and the available resources to be spent on the treatment.

\section{CONCLUSION}

In conclusion, in our analysis of clinical and economic outcomes of lamivudine and telbivudine, for treating HBeAgpositive and HBeAg-negative patients, both strategies are effective, whereas the effectiveness of telbivudine is slightly higher than that of lamivudine. However, comparing the costeffectiveness, lamivudine is more cost-effective than telbivudine. Managers and professionals have to choose the appropriate therapy to patients according to the available budget.

\section{REFERENCES}

1. Elgouhari HM, Abu-Rajab Tamimi TI, Carey WD. Hepatitis B virus infection: understanding its epidemiology, course, and diagnosis. Cleve Clin J Med. 2008; 75(12):881-9.

2. Palumbo E. Lamivudine for chronic hepatitis B: a brief review. Braz J Infect Dis. 2008; 12(5):355-7.

3. Barcena Marugan R, Garcia Garzon S. DNA-guided hepatitis B treatment, viral load is essential, but not sufficient. World J Gastroenterol. 2009; 15(4):423-30.

4. Souto FJ, Piraja AC, da Silva GS, Bottecchia M, Gomes SA. [Long-term use of lamivudine for treating chronic hepatitis B in the State of Mato Grosso]. Rev Soc Bras Med Trop. 2007; 40(1):18-24.

5. Keeffe EB, Dieterich DT, Han SH et al. A treatment algorithm for the management of chronic hepatitis B virus infection in the United States: 2008 update. Clin Gastroenterol Hepatol. 2008; 6(12):1315-41; quiz 286.

6. Lok AS, McMahon BJ. Chronic hepatitis B. Hepatology 2007; 45(2):507-39. 
7. Nguyen $\mathrm{MH}$, Keeffe EB. Chronic hepatitis B: early viral suppression and long-term outcomes of therapy with oral nucleos(t)ides. J Viral Hepat. 2009; 16(3):149-55.

8. Ministério da Saúde. Protocolo Clínico e Diretrizes Terapêuticas para o Tratamento da Hepatite Viral Crônica B e Coinfecções. In: Secretaria de Vigilância em Saúde - Departamento de DST AeHV, editor.: Programa Nacional para a Prevenção e o Controle das Hepatites Virais; 2009. p. 128.

9. Ferreira MS, Borges AS. Advances in the treatment of hepatitis B. Rev Soc Bras Med Trop. 2007; 40(4):451-62.

10. Kurashige N, Ohkawa K, Hiramatsu N et al. Lamivudine-toentecavir switching treatment in type $\mathrm{B}$ chronic hepatitis patients without evidence of lamivudine resistance. J Gastroenterol 2009; 44(8):864-70.

11. Ferreira MS. [Diagnosis and treatment of hepatitis B]. Rev Soc Bras Med Trop. 2000; 33(4):389-400.

12. Lai CL, Gane E, Liaw YF et al. Telbivudine versus lamivudine in patients with chronic hepatitis B. N Engl J Med. 2007; 357(25):2576-88.

13. Liaw YF, Gane E, Leung N et al. 2-Year GLOBE trial results: telbivudine Is superior to lamivudine in patients with chronic hepatitis B. Gastroenterology 2009; 136(2):486-95.

14. Mota DM. Avaliação Farmacoeconômica: instrumento de medida dos benefícios na atenção farmacêutica. Acta Farm Bonaerense 2003 ; 22:73-80.
15. Brennan A, Bansback N, Reynolds A, Conway P. Modelling the cost-effectiveness of etanercept in adults with rheumatoid arthritis in the UK. Rheumatology (Oxford) 2004; 43(1):62-72.

16. Castelo A, Pessoa MG, Barreto TC, Alves MR, Araujo DV. Cost estimates of chronic hepatitis B virus for the Brazilian unified health system in 2005. Rev Assoc Med Bras. 2007; 53(6):486-91.

17. Hou J, Yin YK, Xu D et al. Telbivudine versus lamivudine in Chinese patients with chronic hepatitis B: Results at 1 year of a randomized, double-blind trial. Hepatology 2008; 47(2):447-54.

18. Iloeje UH, Yang HI, Su J, Jen CL, You SL, Chen CJ. Predicting cirrhosis risk based on the level of circulating hepatitis $\mathrm{B}$ viral load. Gastroenterology 2006; 130(3):678-86.

19. Chen CJ, Yang HI, Iloeje UH. Hepatitis B virus DNA levels and outcomes in chronic hepatitis B. Hepatology 2009; 49 (5 Suppl):S72-84.

20. Veenstra DL, Sullivan SD, Lai MY, Lee CM, Tsai CM, Patel KK. HBeAg-negative chronic hepatitis B: cost-effectiveness of peginterferon alfa-2a compared to lamivudine in Taiwan. Value Health 2008; 11(2):131-8.

21. Lam ET, Lam CL, Lai CL, Yuen MF, Fong DY, So TM. Healthrelated quality of life of Southern Chinese with chronic hepatitis B infection. Health Qual Life Outcomes 2009; 7:52.

22. Levy AR, Kowdley KV, Iloeje $\mathrm{U}$ et al. The impact of chronic hepatitis B on quality of life: a multinational study of utilities from infected and uninfected persons. Value Health 2008; 11(3):527-38. 